\title{
Crop Production in Oyo Empire: Earliest Times to 1930
}

\author{
Jonathan Oluropo FAMILUGBA, Ph.D. \\ Department of History \\ School of Arts and Social Sciences \\ College of Education \\ Ikere - Ekiti,Ekiti State \\ Nigeria
}

\begin{abstract}
The primary occupation of the Yoruba who inhabits Oyo Empire prior to 1930 was agriculture in which crop production played a dominant role. Hence, this paper intends to examine crop production in Oyo Empire from the earliest times to 1930. The paper examines the tenure system as it has to do with land utilization and ownership among the people. The work further examines the production process from planting to harvesting of agricultural produce. The work concluded by pointing out that the pre-colonial economy witnessed a considerable growth in agricultural practices; and that these economic activities provided the wealth of the society and individuals, thereby leading to the development of trade and commerce within the Empire prior to 1930.
\end{abstract}

Keywords: Agriculture, Economy, Farming, Production, Development

\subsection{Introduction}

It is believed that no one can hope to fully understand the economic performance of the present epoch without an adequate knowledge of the historical experience and the nature of the people's economy prior to European colonisation. Hence, in this paper, attention shall be focused on examining Crop production among the Yoruba in Oyo Empire from the earliest times to 1930. Although Oyo is our central focus here, this subject, however, will be examined within the context of Yoruba economic system.

\subsection{Geographical Location}

Yoruba land in which Oyo is situated stretches on the west from around the area of Badagry to around Warri and inland to the Niger around Latitude 9oN. The land spread westwards cutting across the whole of Dahomey (now Republic of Benin) and reaching into the East of Togo. The weather is fairly stable with two clearly defined seasons in the year, the rainy and the dry seasons. The rainy season lasts from about April until September, with a short relatively dry spell during the first week of August. The dry season lasts from September to April with cold wind from the Sahara called harmattan which commences from November to February. Yoruba comprises several distinct sub-groups, the most important being Oyo in the North, the Ife, Ijesha, Ekiti and Ondo in the East, the Ijebu Egba in the South, and Ketu in the West. (Law, 1973:207). The Oyo Kingdom which latter metamorphosed into an Empire was surrounded by foreign elements. (Adegbulu, 2015:189). The Nupe Kingdom bothered Oyo Empire in the Northeast, while Ibarapa occupied the Northwest. The climate is suitable for agriculture, making it possible to have two harvest in one year. (Akinjogbin \& Ayandele, 1999:121).

\section{Land Tenure System}

As an agrarian society, the primary occupation of the Yoruba people of Oyo Empire prior to European colonisation is farming in which land played a vital role, hence, the need to examine the tenure system as it was practised in the precolonial period. Land tenure system regulates the duration of ownership and utilisation of land.(Cohen, 1980:349) It is also the customary system by which people can own, use, and dispose of land in any given society. Perhaps, the most important feature of agriculture in the region during the pre- colonial period was the land tenure system. Land was, however, not scarce but the organisation of land for economic activities was regulated by by-laws and customs enforced by the communities or their leaders (Falola, 1992:7-10). This law embodies those legal and contractual or customary arrangements whereby people engaged in farming gain access to productive opportunities on land. (Adesina, 1989: 3). It constitutes the rules and procedures governing the rights, duties, liberties and exposure of individual and groups in the use and control over the basic resources of land and water. (Fabiyi, 1979:237) While the laws varied from one state to the other, they, however, had some common features. 
Firstly, land was jointly owned though it was being administered by the community leaders or rulers. At the head of each community was the Oba or chiefs- in-Council who held the community land in trust for every member. (Alao, 1979:286)

Secondly, all descent groups in a community had right to land and such right remained inviolate except in cases of external conquest. Therefore, an individual possessed right to land for any legitimate economic activity only through membership of a descent group. Thirdly, a non-indigene of a particular community could also obtain land from a host community on certain conditions which included the payment of a token gift known as isakole such as kola nut. The gift, whether in cash or kind, was never regarded as a payment for the land but rather as an acknowledgement of the fact that the stranger recognised the ownership of the host who gave him the land to use. Lastly, the descent group, the

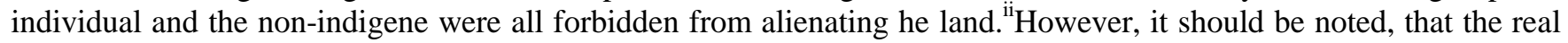
unit of land holding is the family, and that the ascription of ownership of land to the community or village is only accurate if viewed as a social aggregate. For, even within the community or the village, actual occupation and control are decentralised, and the family rather than the community or village, in fact, exercises acts of ownership. The main interest of the community or village is purely to maintain group solidarity both socially and politically.(Agboola, 1964:24-25)

Agriculture in pre-colonial Nigeria thrived alongside pastoral communities producing adequate food for the producer's family needs as well as surplus for inter regional and external commerce. The pattern of land holding, the type of land rotation practised and the volume of mixed cropping engaged in were some of the features of their farming methods.(Agboola, 1964:24-25).

\section{Agricultural Practices}

Crop production among the Yoruba of Oyo just like any other West African country had passed through several phases of development. These, among others, include independent approaches to several indigenous seed crops in the forest area after many centuries of trial and error. (Adesina,1989:1) Each community specialises in the production of particular food crop which could be made available to others at a price. By the beginning of the $19^{\text {th }}$ century, a variety of crops both indigenous and imported were being grown in various parts of Yoruba land. Those food crops consisted of mainly tubers like yams, cocoyam, cassava oil palm, maize, cotton, ground nut, kola Nitida and kola Acumunata, (Adediran, 1986:119). The pre-colonial economy was thus a collection of communities engaged in production of crops primarily as an economic activity necessary for their subsistence, producing and processing food for their family needs and for the localised markets. (Adesina, 1989:82)

The economy of virtually every community in Yoruba land has traditionally been based on agriculture and the primary purpose of agricultural activities was purely subsistence, but as time went on, the needs and tasks broadened. The Yoruba farmers began to produce to meet the domestic needs of their immediate families and to reserve the surplus for exchange.(Ayodele, 1999: 45) The exchange was initially hampered by lack of the means of exchange- money. In an attempt to proffer solution to the problem of exchange, the people made recourse to the barter system. ${ }^{\text {iil }}$ Inter and Intraregional markets were essential and important as the result of contact between various ecological regions, differential needs and trade.(Akubor, $2010: 96$ ). These gave rise to, and increased economic specialization. Specialization helped to distinguish different kinds of economic activities and the level of their inter-dependence. Economic activities were organized either on group/clan or on individual basis or guilds. (Akubor, $2010: 96$ )

The Yoruba generally accumulated agricultural surplus which they preserved against natural disasters like famine. The result was the establishment of $o g b a^{\text {iv }}$ (granaries) all over the area. The people were certainly aware that difficult times would inevitably arise occasionally. So the problem was not just to increase production (for tribute, consumption and trade), but also to store a reserve of the produce against raining days.(Bradbury, 1957: 62)

Farming activities always began with clearing the bush in preparation for cultivation. The clearing could be done between August and October for early yam cultivation while the late yam preparation was done between January and March awaiting the early rain which would enhance easy cultivation and planting. The nature of crops planted during this period by the Yoruba people were primarily food crops such as yam, cocoyam, maize, cow pea, cotton. Farmers cultivated about two to three crops each year. (Elegbeleye, pers. Comm.) ${ }^{\mathrm{v}}$ Farmers generally raise farmsteads very close to their residences in towns and villages, this kind is referred to as Oko Etile and a more distant one generally very far in the forest Oko Egan. They work approximately between $7 \mathrm{am}$ and $5 \mathrm{pm}$ on the farm nearer home with short intervals for meals and return home. At the distant farms, they remain there for weeks and months before returning home sometimes only to attend annual festivals. (Johnson, 1997: 118). Crops like maize were usually harvested early mid-season (from July where as long term crops like cassava and yam, were harvested at the end of the rains. 
The time differential between yam (a long duration crop) and maize (a short duration crop) was very significant because the maize was both as good insurance as well as a good food while waiting for harvesting of yam which has greater popularity as food stuff. (Ogundeji, pers. Comm..) vi

Farming activities included clearing the bush in preparation for cultivation (usually between the months of March and April), and burning the bush. Rotational bush fallow was generally adopted with farms rotating around fixed settlements. When a farm lost fertility, it was abandoned for four or more years. Deliberate burning of the bush created ash which helped the soil by reducing acidity and improving the fertility. Inter-cropping legumes was also adopted to improve the fertility of land. In most areas, bush burning was practiced along with hunting especially small animals such as rodents. (Ogundeji, pers. Comm.) vii

In the area of techniques, the practice of farming among the Yoruba involved the use of simple implements such as (oko) hoe, (ada) cutlass and (ake) axe. ${ }^{\text {vii }}$ These local implements were made from locally sourced raw materials designed by the blacksmith. However, in order to boost production, the farmer employed the labour of his wife/ wives, children and slaves on his farm. This enabled him to produce enough to last him and his family the year round and to have excess for exchange.(Akinfemiwa, $1994: 118$ )

Farmers stored their harvested crops on the farm and also in the compound. Yam tubers meant for sale were stored on the farm, either in small huts (built with stalks and logs, and served as farmers' temporary shelters) or against a tree or on the ground in shade and covered with leaves or grass and sometimes buried in the ground.(Oluwatoyin, pers.comm. $)^{\text {ix }}$ Yam were stored whole and those needed for marketing were collected a day to the market in the area or on certain days for transport to the market. Their heads' (seed yams) were cut to be planted the next season.

Maize was stored in granaries (oke-aja) at home. They were made of sticks and bamboo and had grass roofing. ${ }^{\mathrm{x}}$ The Yoruba used this form of preservation in order to ensure adequate ventilation and to prevent the grains from becoming damp and mouldy. The seed plants were separated from those stored. They were kept unthreshed in house, on a shelf of bamboo or wood underneath the roof and sometimes underneath the roof in the kitchen (especially maize). Before grains were marked or prepared for cooking, they were threshed, but sometimes maize were sold unthreshed. Threshing was done in the compound or outside where the grains were beaten with sticks on the floor or pounded in a big wooden mortar. The residue was used to feed animals.

However, with the coming of the Europeans, there was a marked change in the nature of agricultural produce in western Nigeria. The people that had hitherto been primarily engaged in the production of food crops such as yam, cocoyam, cassava, now had new crops introduced to them. Crops such as cocoa, cotton, coffee, rubber, which had earlier been tried in other tropical colonies of South America and Asia and were discovered to have done well on Tropical soil and climate, were then introduced into the Nigerian economy (Agaldo, 2005:81). In view of the favourable geographical condition of the South Western Nigeria which was similar in nature to that of South America as a tropical region, cocoa cultivation was introduced.

The earliest $\operatorname{cocoa}^{\mathrm{xi}}$ farms in western Nigeria were established around Lagos in the 1880s and 1890s. (Berry,1975:37). The cocoa farming activities were engaged in by African merchants based in Lagos whose businesses had suffered from the prolonged decline in the prices of palm produce during the late $19^{\text {th }}$ Century slump in world trade (Hopkins, 1968: 592). By 1900, cocoa was probably known to at least a few people in some major Yoruba towns. Most of the cocoa farming activities were carried out near Agege and Otta, although a few Ijeshas and Ondos planted cocoa near their trading communities in Southern part of Ondo (Berry,1975:37). Cocoa seedlings were procured from the government Botanical garden at Ebute Meta, Lagos. The cocoa farming activities practised at Agege and Southern Egba land served as an important source from where the knowledge about the planting of cocoa were disseminated to other parts of Western Nigeria(NAI, 1951) ${ }^{\text {xii }}$.

The early missionaries were highly instrumental at promoting the growth of cocoa in Western Nigeria during this period. Trading merchants and clergymen from Lagos introduced the planting of this new crop to the people. One of the renowned clergymen in this regard was Rev. Charles Philips who, in January, 1895 encouraged Christian converts in an Ondo village to take up the cultivation of cocoa and oil palm. In 1903, he also held a meeting with the elders of Ife and Ilesha Churches and advised them to encourage their members to form a cooperative society in the name of the church to cultivate cocoa farm as a source of revenue for the church (NAI, 1951) xiii. $^{\text {. }}$

Cocoa was first cultivated in Oyo Province in an experimental 'model farm' established at Ibadan in 1899. (Atanda, 2017:527). Farmers in Oyo and its environs were equally encouraged to cultivate the crop. Atanda noted that the crop throve well in the Province except in Oyo Division and some parts of Ibadan division. There are no evidence to show what quantity of cocoa that was exported from Oyo Province before 1919. But in 1919 and 1920, statistics revealed that 13,790 tons and 8,174 tons respectively were exported from the Province. (Atanda, 2017:527). 
Until the crash in the world price of cocoa following the depression of 1929-32, cocoa was a profitable industry in the area. Cocoa production enjoyed a boost in 1920 when its price rose to $£ 82$ per ton in Ibadan. Undoubtedly, cocoa was one of the most important cash crop introduced into Oyo Province.

At the beginning of the $20^{\text {th }}$ century, concerted efforts were made by the colonial administration to encourage the growth of cotton in Nigeria (Faluyi, 1996:177). Prior to the arrival of the British, the people of Oyo had been engaged in the cultivation of cotton, though on a small scale primarily to meet domestic needs. (Atanda, 2017:525). It was not until the colonial era that the growing of cotton on a large scale and for export purposes was encouraged. The main objective of the Colonial Administration was to ensure a steady supply of cotton to cater for the raw material needs of the British sprawling textile industries especially as the supply of American cotton during this time was unreliable (Komolafe, 1996:13). The main body responsible for the growth of cotton in south western Nigeria as well as in any other part of West Africa was the British Cotton Growers Association (B.C.G.A) (Komolafe, 1996:13) In an attempt to make northern Nigeria a rich cotton producing area, Lugard in 1901, procured some American cotton seeds from Britain and distributed them to the local farmers in Northern Nigeria. It was later reported that the American cotton seeds did very well on northern Nigerian soil (NAI, 1922:16) ${ }^{\text {xiv }}$. This positive report on the performance of the cotton seeds on Northern Nigerian soil served as an impetus for the BCGA. It should however be pointed out that the BCGA was assisted in its effort at developing the cotton industry by the political officers who willingly cooperated with the merchants in encouraging the local farmers to grow more cotton and in distributing cotton seeds to them.

The BCGA encountered some problems in its activities regarding the growth of cotton in Southern Nigeria. For instance, its attempt to secure a large expanse of land covering 15,000 acres in Ibadan for cotton cultivation met a stiff resistance from the Ibadan Council on the ground that if the proposed land was granted, it would deprive the local farmers of their land and inflict a lot of economic hardship on them. However, when BCGA was able to secure 5000 acres of land, it discovered that cotton would not thrive on a large scale as formerly proposed; hence, corn was planted instead. (Atanda, 2017: 526). In spite of this initial challenges faced by BCGA, it did not give up in its efforts at encouraging the growth of cotton, nor were its efforts entirely fruitless. Atanda noted that raw cotton bought by the BCGA from places like Ibadan, Oyo, Eruwa Road Station and Iwo, all in Oyo District in 1907was estimated at 550 tons. (NAI, 1907:84) ${ }^{\mathrm{xv}}$ In 1921, the BCGA purchased 9,687 tons of cotton in Oyo province valued at about $£ 316,000$. By 1930, however, the production of cotton in Oyo and its environs had witnessed a downward trend. In spite of the various means employed by the British firms and officials to promote cotton industry in Nigeria, there was no more appreciable increase in its production beyond the 1930s (Komolafe, 1996:14).

This downward trend observed in cotton production, however, was not unconnected with the nature of the soil and the general climatic condition of the environment which was largely unfavourable to commercial production of the American cotton (Adaramoye,2014: Interview) ${ }^{\mathrm{xvi}}$. In the few areas where experimental farming was conducted, it ended in abysmal failure. This was not only due to the nature of the land; the American cotton was highly susceptible to pest and other diseases (Olarewaju,pers.comm. $)^{\text {xvii }}$. The colonial administrators however recognised the existence of indigenous cotton prior to colonial domination but which was considered not suitable for overseas textile industry due to its low quality (NAI, 1922:16) xiii $^{\text {. }}$

Furthermore, the local farmers paid more attention to the cultivation of such food crops as yams, cassava, maize, rather than cultivating cotton farms (Elegbeleye, pers.comm.) ${ }^{\text {xix }}$. Secondly, the volume of cotton being consumed by the local weaving industry was much. For example, the people produced locally woven materials called Ikeji, iketa, ikerin cloths made from cotton (Adaramoye, pers.comm) ${ }^{\mathrm{xx}}$.

In spite of all the efforts, cotton production did not witness any appreciable increase. In view of this, the colonial authority took some decisions (NAI,1922:16) ${ }^{\mathrm{xxi}}$. Firstly, that commercial production of cotton should be restricted to the North where the nature of the soil and the climate favoured the production of cotton on a large scale, and more so that the American cotton seed did very well on Northern Nigerian soil; secondly, that since the American cotton did not do well in the South due to the effect of pests and diseases, and due to the nature of the soil which do not favour the cultivation of the American cotton, that the question of export do not arise. In spite of all the aforementioned challenges, however, there was no doubt that for the greater part of the nineteenth century, the cotton growing industry did well. In its time of prosperity, it certainly brought wealth to those who participated in the cotton industry either as farmers or as traders. (Atanda, 2017: 527).

\section{Oil Palm Production}

Palm oil has been produced in Yoruba land since time immemorial and its early development cannot yet be traced. The greatest output came from individual homesteads; it was a true example of a cottage system of production. The methods were traditional with simple equipment ( e.g. cutlasses, and climbing rope) and labour was closely integrated within the domestic routine. 
Traditionally, the work of palm oil collection and preparation was shared by the whole household.(Omotoyinbo, pers.comm. $)^{\text {xxii }}$ The young men would cut down the fruit branches; cut the bunches into pieces so that the fruits fell out; the women collect and separate the fruits from the shafts and made ready for processing; the fruits were then boiled and pounded to separate the oil, kernels and waste fibre.

The household thus participated in the production of palm oil, and there were real divisions of labour and frequently outside cooperation was recruited as well. In traditional method, the palm fruits were tramped into a mortar, pounded with a pestle and then mashed with the feet. This was done by women in cooperation with the young boys and girls. But with the growth of the palm oil trade in the second half of the $19^{\text {th }}$ century, a new and more efficient technique was devised. Additional scale of operation was facilitated by pouring the boiled palm fruits into a canoe like earthen trough specially designed for that purpose. (Omotoyinbo, 2016: Interview) ${ }^{\text {xiii }}$ The workers, mostly young men, stood inside the earthen vessel and trod on the palm fruits vigorously using one foot until the pulp were separated from the fruit. The pulp was removed and strained to produce a solution which together with the liquid from the trough, was then boiled and allowed to stand. The oil rose to the surface and was skimmed off. The remaining fibres were reboiled and after further straining were picked over by hand to extract the nuts, which were put aside for cracking with stones.(Ogen, 2003:11) This played an important part in helping to get the full value from the palm tree and in providing protein for the community.

It was a fixed principle that men took the earnings from the sales of oil, while the women regarded the kernels and other by-products as their own. This was partly because of the division of labour in the production and also because of the kinds of tribute traditionally paid by the sexes (men in oil and women in various fruits). Thus, while the men had the epo(oil), the women had kernels (ekuro), kernel oil (ikete) for eating yam, and (adin ) made from palm nuts. The Palm plantations and oil palm industry was vital to the economy of the people. The bonds from the palm trees, coconut trees and date palm were used for roofing and making of brooms, basket, straw tray, and mats. $\quad$ It is doubtful whether palm oil produced in Oyo Empire was exported during this period covered by this study as there were no records in this regard. What is certain is that most of the palm oil produced was consumed locally; hence palm oil was regarded as article for internal trade.

Efforts were made to extend the palm oil industry to Oyo Division where palm trees grow naturally only along streams, by establishing palm tree plantations. Thus, by 1923, oil palm plantation had been established in ten towns in Oyo Division. There are Oyo, Iseyin, Okeiho, Iganna, old Okaka, New Okaka, Out, Saki, Ilero, and Ago Are (NAI, 1923: 174).

Inter and intra-regional trading networks were an important part of the pre - colonial economy among the Oyo and her neighbours. A number of factors gave rise to, and promoted, the exchange of goods and services in pre-colonial Yoruba land.(Falola,1992:16) Firstly, production of goods had gone beyond subsistence level; the surplus had to be disposed of. Secondly, there was specialisation of economic activities in every community and one occupational group needed the products of another: for example, the craftsmen and the farmers would mutually exchange their products to meet their individual needs. Indeed, no Yoruba community was self sufficient in all its requirements. Exchange policy in the pre-colonial economy of Africa in general and that of the Yoruba in Oyo Empire in particular probably started through non-market institutions of gifts, inheritance, bride-wealth, payment of tribute and taxes, and the routine supply of goods and commodities by heads of households to their members (Falola,1992:16). Thus, large quantities of goods were exchanged in all communities without the use of currency. The goods exchanged were more often 'a validation of existing social relationship'. However, the fact that the exchange was based on social relations limited the flow of goods to a few people and to a few areas. This eventually led to exchange based on rudimentary market principles called 'barter'. (Falola, 1992:16) For a long time, the principle of exchange by barter predominated. Numerous articles were involved in these trading networks. Internally, producers exchanged their products for those they did not produce themselves and which they actually needed.

The barter system was later discovered to be inadequate as it promoted imbalance and inequality in the process of exchange and to a great extent also restricted trading activities to a small area. The inadequacies of the barter policy eventually facilitated the development of the infrastructure of commerce such as currencies, markets, languages of communication, trade routes and professional traders. (Falola, 1992:16)

There were periodic markets within the various towns and villages in Oyo Empire which were organized in form of a cycle. It could be every 5 or 9 days depending on the area and what the arrangement was. Virtually every town and village had its own market days which were periodised. The availability of periodic markets gave time for the arrival of traders from distant places, encouraged the assemblage of a variety of trade items, and reduced the time required for marketing and allowed people to visit almost every market in a particular area in turn. (Falola,1992:16) 
One characteristic of these markets is that they were often sited in open spaces usually close to the residences of the leading community members, with trees, stalls or tents providing shade. Sellers of similar commodities sat in groups, an arrangement which helped buyers to easily locate the commodities they wanted to buy. (Falola, 1992:17) Secondly, the markets provided a central place where various craftsmen, barbers and other occupational groups rendered services to their clients.

Periodic markets attracted more people from two or more communities, had a larger volume of trade, and served as centres for distribution of farm produce, processed food items, products of crafts, etc.

The markets were well organised and trading went on in such a peaceful atmosphere, which was achieved through the agency of market officials, trade guilds, and customary laws and policies prohibiting attack on defenceless market traders. (Falola, 1992:17). Prior to the arrival of the European, the Yoruba have their own medium of exchange. About three types of currencies were used in trade transaction. The first type was produce currency (i.e., exchange units based on key product of the region). Slaves, salt, cloth, horses and cows come within this category. The second type was metal currency consisting of iron, gold, copper and brass objects. Cowry, the third type of currency was more widespread than the others. (Falola, 1992:17)

External trade on its part was operated at two levels. ${ }^{\text {xxiv }}$ The first was regional, involving communities within the same geographical region. The second was international, linking one state with others. The trade could also be between two or more sub-regions. The various African societies also had long distance traders who specialised in carrying goods from one market to another. The external trade ensured the distribution of goods between areas of surplus production and areas of scarcity among states and regions. This situation was witnessed between Egba at Abeokuta and the Awori at Ota, and between Ibadan and Ijebu from 1850s till about the end of the Century. (Ajayi \& Akintoye, 1999:298). As a result, trade became such an important factor of inter-state relations in Africa that trade relations were often maintained even in times of war.

\section{Impact of the $19^{\text {th }}$ Century Wars on Crop Production in Oyo Empire}

The $19^{\text {th }}$ century wars had tremendous impact on agricultural activities throughout the length and breadth of Oyo Empire. The state of insecurity, destructive nature of wars and the dislocations occasioned by the war were enormous. It should be noted that this period coincided with the abolition of Atlantic slave trade and the introduction of legitimate trade in articles such as oil palm. Ironically, rather than out rightly putting an end to trade in slaves, the captives of war between Oyo and its neighbours were converted to slave labour. This was due to the fact that the production and transportation of the articles of legitimate trade created a great labour demand. On regular basis, slaves were taken from the war front in the interior to the main market towns in places such as Ibadan, Abeokuta and Ijebu towns.

Farmers who were famous engaged the services of these slaves in raising large expanse of farm for commercial purposes. Ajayi and Akintoye noted that a woman chief in Ibadan engaged the labour of two hundred slaves working on her farms in 1870.(Ajayi \& Akintoye, 1999:297) slaves were engaged in cultivating extensive farms; the extent of the farm owned by large scale farmers was determined by the number of slaves at their disposal. The slaves apart from being engaged on the farms were also used to build impressive sprawling compounds and manage huge trading establishments.(Ajayi \& Akintoye, 1999:297)

In centres of large concentration of population such as Ibadan, Abeokuta, Oyo and Ife, the problem of coping with the food requirements would have posed a grave problem; but since the economy was still largely agrarian, the initial difficulties of settling a large number of refugees who were displaced by the $19^{\text {th }}$ century Yoruba wars were easily overcome. The internally displaced people themselves continued to engage in crop production in these new settlements. Consequently, there was tremendous increase in food crop production. The surplus was sold in the local markets such as Bashorun Oluyode of Ibadan did to his farm products. (Ajayi \& Akintoye, 1999:298). In some cases, regular trading exchanges occurred between areas where there was surplus in food crop production and other areas where there was food scarcity. This situation was witnessed between Egba at Abeokuta and the Awori at Ota, and between Ibadan and Ijebu from 1850s till about the end of the Century. (Ajayi \& Akintoye, 1999:298).

There were large scale distortions and disruption of farming activities during the Yoruba wars of the nineteenth century as kidnapping and molestations of farmers on their farms held sway as a military strategy. This military strategy featured prominently during ijaye war when Ibadan in 1861 conquered some upper Ogun towns on which Ijaye depended for its food supply. This hastened the final defeat of Ijaye in 1862. Thus, this state of insecurity had negative impact on crop production thereby distorting the agricultural economy of Oyo Empire. The extent of farm land cultivated under the control of each of the major towns in Oyo Empire reflected the protection that each town could afford its people. (Ajayi \& Akintoye, 1999:298) 


\section{Conclusion}

The focus of this paper is on crop production in Oyo Empire from the earliest times to 1930s. The paper carried out a review of the agricultural economy of the Oyo people within the framework of Yoruba political economy. It examined the tenure system and observed that land was generally abundant and its utilisation was guided by customary laws administered by the community leaders.

The paper pointed out that the Oyo people that had only specialised in the production of food crops later had foreign crops such as cocoa, coffee, cotton, introduced to them following European colonisation. However, in spite of the various challenges which confronted the cultivation of these cash crops as already pointed out in the paper, the cultivation of these crops no doubt brought wealth to those farmers who participated in them. The paper however, observed that the $19^{\text {th }}$ century wars had tremendous impact on both production of crops and general trading activities as there was general insecurity throughout the length and breadth of the Empire.

${ }^{\mathrm{i}}$ The Yoruba tribe stretches from the West from around the area of Badagry to around Warri and inland until they almost reach the Niger around latitude 9 degree N. Indeed, certain parts of the Niger formed the boundary between it and the Nupe, around latitude $5 \mathrm{~N}$, they spread westward cutting across the whole of Dahomey (now Republic of Benin) and reaching into the east of Togo. From the coast, the country rises gradually from low lying swampy regions with thick undergrowth to forest belt and finally semi-or derived savannah, which in Porto Novo (Ajase), reaches almost to the coast. See Reuben K,Udo, Environments and Peoples of Nigeria, In Obarolkime (ed.), Groundwork of Nigerian History, Ibadan, Heinemann Educational Books Plc., p.16

ii This is an out and out transfer by the grantor, having enough land to spare, to the grantee or grantees that usually enjoy perpetuity of tenure subject to good behaviour. The chief or the family head, as the case may be, will either go in person or delegate someone else on his behalf to go, with the intended grantee in sight of the parcel of land. The extent of the land will then be demarcated sometimes by placing a mound of earth at each of the four corners and sometimes by planting some trees in the same position as evidence of the boundary. Then kolas are split, and wine drank in celebration of the occasion to which those present are expected to be witnesses in any future dispute, since the customary law is unwritten. The condition attached to gifts of land must depend on what has been agreed upon between the two parties and the relevant customary rules. See Akinola A. Agboola, p.24-25

iii The barter system was equally hampered by a number of factors. This ranges from the economic indices of price allocation to commodities, either on local or inter regional basis; the highly perishable nature of the agricultural products; the problem of identical production within the same locality; and that of transportation of the heavy products from the point of production to the place of exchange. See Ayodele Cornelius: Topics on Economic History of Nigeria, p.45

${ }^{\mathrm{iv}}$ This was a traditional storage facility adopted by the Yorubas to preserve their surplus agricultural products

${ }^{v}$ Interview with Chief Andrew Elegbeleye, 95 years, Farmer, 31, Aafin Street, OrunEkiti, 16/3/2014

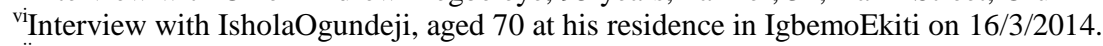

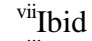

viii Personal observation

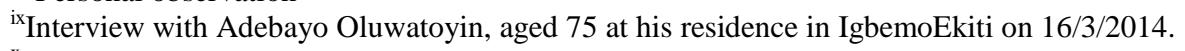

${ }^{\mathrm{x}}$ Ibid

${ }^{x i}$ Cocoa is a major economic tree crop in Nigeria. Sara s. Berry, Cocoa, Custom And Socio- Economic change In Rural Western Nigeria; Oxford, Clarendon Press, 1975. p.37

${ }^{x i i}$ As part of efforts made by the colonialist at promoting the growth of cocoa was the establishment of nursery centres from where citrus and seedling were being distributed to the farmers at subsidised rates. Examples of such places where nursery farms were established were Ilesha, Oyo, and Iseyin See N.A.I, 1222/2, Oyo Provice/1/855, 1951,p.6

xiii Members of the local community were encouraged to form cooperative societies which would make them qualify to benefit from government. However, there are certain conditions that must be fulfilled before the cooperative group could be duely registered. These are the size and location of land offered; the nature of crop to be planted; Agricultural officer's confirmation of the suitability of the soil; Estimated cost of establishment and all relevant facts about the acquisition of the land.See N.A.I File No 4504/1: Agricultural Development in Western Region 'Igangan Co-operative Group Farming society. P.610. See also Sara S. Berry. Op.cit. p.41

${ }^{x i v}$ NAI. 16 Min. Agric/1/41 No 0243/37 Agricultural Ordinance, 1922

${ }^{x v}$ Annual Report for the Colony of Southern Nigeria, 1907, p.84

${ }^{\mathrm{xvi}}$ Interview with Mr. Fabarebo Adaramoye, Orun Ekiti, Age 80, March $16^{\text {th }} 2014$

${ }^{x v i i}$ Interview with Mr. Daniel Olarewaju, Aba Olorunda, Igbemo Ekiti, Age 92, March 16, 2014

xviii NAI, 16 Min. Agric/1/4 No 0243/53 ' Cotton Growing in The Southern Province, 1922 Latter in 1952, As part of efforts made by the colonial government at encouraging the cotton industry, textile training industries were established at some centres such as Ado Ekiti and Oyo. The centres were specially established not only to produce locally woven clothes by the weavers but equally to train those who were willing to acquire the skill. . Men were not even left out of the thriving opportunity in the textile industry most especially the exservicemen who took advantage of the opportunity. It was on record that out of the thirty four trinees at Ado Ekiti centre, only seven were women spinners. See N.A.I File No 1222, Oyo Pro./01/853, 'Textile Development'Agricultural Development, General Correspondence 1952, p.20

${ }^{\text {xix }}$ Interview with Mr. Andrew Elegbeleye, op.cit.

${ }^{\mathrm{xx}}$ Interview with Mr.Fabarebo Adaramoye Lucas, A native of Orun Ekiti, Age 90, March 16, 2014.

${ }^{x x i}$ NAI, 16 Min. Agric/1/4 No 0243/53 'Cotton Growing in The Southern Province, 1922

${ }^{x x i i}$ Interview with Madam Elizabeth Omotoyinbo, aged 80, the Olori (wife) of the late Oba Omotoyinbo, the Onisin of IsinbodeEkiti on $13^{\text {th }}$ April,2016. 


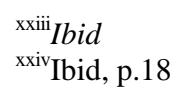

\section{References}

Adediran, A. (1986) "The Yoruba Kingdoms." In Falola T, and Adediran A. (eds), A New History of Nigeria for Colleges, Book One (Peoples, States and Culture Before 1800), Ikeja: John West Publications Ltd. P.119.

Adesina, O. C.( 1989) “ A Historical Evaluation of Western Nigeria Government Agricultural Policy, 1951-1966.” M.A Thesis, ObafemiAwolowo University, Ile -Ife p.1.

Agaldo, G.S. ( 2005). "A Survey of the Impact of Colonial Agricultural Policies on Nigerian Agriculture." Journal of Economics and Financial Issues, vol.2, Nos $1 \& 2$.

Agboola, A.A. (1964). "Land Tenure System in Western Nigeria and How it can be Improved." College of Agriculture, Department of Agricultural Economics, Unpublished Material, Pp.24.

Ajayi, J.F. and Akin toye, S.A. (1980) "Yorubaland in the $19^{\text {th }}$ Century." In Obaro Ikime (ed). Groundwork of Nigeria history. Ibadan: Heinemann Educational Books (Nigeria) Plc.

Akinfemiwa, A.M. (1994). Ile Oluji: Traditions, Growth and Neighbours, Ibadan, Adeline Ventures.

Akinjogbin I.A. and Ayandele, E.A, (1980) "Yoruba up to 1800" In Obaro Ikime (ed), Groundwork of Nigeria History. Ibadan: Heinemann Educational Books (Nigeria) Plc.

Akubor, E. O.( 2010) "Colonial Domination and Cash Crop Production in Esan Division of Nigeria." 1906-1960, Unpublished Doctoral Thesis Submitted to the Department of History, Ahmadu Bello university, Zaria, p.96

Alao, J.A. (1979). " A Review of Traditional Authority and its Impact on the Acceptance of Agricultural Innovation in Western Nigeria" Ife Journal of Agriculture, Vol. 1, (no. 2), p.286,

Atanda, J.A. "Economic and Social Changes in the New Oyo Empire, 1894-1934" Falola Toyin (ed), The Collected Works of Atanda, United States of America : Pan-African University Press, p.527

Ayodele, C. O. (1999). Topics on Economic History of Nigeria. Ondo: Crofes Computers, Press \& Publishers, p.45.

Berry, S.S. (1975). Cocoa, Custom and Socio- Economic change in Rural Western Nigeria. Oxford: Clarendon Press.

Bradbury, R.E. (1957). The Benin Kingdom and the Edo Speaking People of South-Western Nigeria.London, Pp.62-63.

Cohen, John M. (1980). "Land Tenure and Rural Development." In Bates, R.H, and Lofchie Prager, M.F, Agricultural Development in Africa. New York, p. 349-399.

Fabiyi, Y.L. (1979) "Land Tenure Reform in Nigeria: Implications of The Land Use Decree For Agricultural Development," Ife Journal of Agriculture, Vol. 1,(no.2) p.237.

Falola, Toyin (1999). "African Pre-colonial Domestic Economy" In Tarik, An Introduction to The Economic History of Pre-colonial Africa. Lagos: Longman Nigeria Plc. Pp.7-10.

Faluyi, Kehinde, (1996), “The Development of Agricultural Exports and Official Intervention in

Produce Marketing." In G.O Ogunremi \& E.K Faluyi eds. An Economic History of West Africa Since 1750: Ibadan, Rex Charles Publication, 1996 p.179.

Hopkins, (1968). "Economic Imperialism In West Africa". Lagos, 1880-1892, Economic History Review, 21, 3 p. 592.

Johnson, Samuel (1921). The History of the Yorubas. Lagos: CSS Limited. (Reprinted with updated Map, 2001).

Komolafe, C.O (1996) "British Attempt To Develop Trade In Cotton and Palm Kernel in Akoko, 1902- 1935". In The Olosunta : Ikere Journal of Social Studies, Vol. 1, No 1, p.13

Law, RCC. (1973). "The Heritage of Oduduwa: Traditional History and Political Propaganda among the

Yoruba." In The Journal of African History, Vol.14, No2 Pp207-222.

Law, Robin (1977). The Oyo Empire, 1600-1836: A West African Imperialism in the era of the Atlantic Slave Trade. Oxford: Oxford University Press, p.32

Ogen, Olukoya (2003). "Urhobo Migrants and the Ikale Palm Oil Industry." In The Nigerian Journal of Economic History Nos. 5\&6, p.11 